\title{
Связь показателей экстерьера у опытной популяции кур пушкинской породы с однонуклеотидной заменой rs313744840 в гене миостатина
}

Пегливанян Г.К., аспирант, младший научный сотрудник

Всесоюзный научно-исследовательский институт генетики и разведения сельскохозяйственных животных (ВНИИГРЖ) - филиал ФГБНУ «Федеральный исследовательский центр животноводства - ВИЖ имени академика Л.К. Эрнста», Санкт-Петербург, Пушкин

\begin{abstract}
Аннотащия: Совершенствование генотипа с помощью ДНК-маркеров обеспечивает точный отбор и ускоряет процесс селекиии 6 животноводстве. Масса тела и качество мяса зависят от множества генов и тесно сбязаны с разбитием скелетных мыши. Было изучено блияние однонуклеотидной замены rs 313744840 6 гене миостатина на показатели экстерьера опытной популяции кур пушкинской породы (102 головы). Оценка экстерьера проводилась 6 бозрасте 330 дней по 17 показателям: жибая масса, длина корпуса, длина корпус+шея, косая длина туловища, длина бедра, глубина груди, иирина груди 6 ключицах, иирина таза, обх6ат груди, обхбат плюсны, обхбат голени, длина плюсны, длина голени, косая длина тела лентой, длина голени лентой, угол груди (градус), длина киля. ПЦР-ПДРФ-анализ прободили с использобанием фермента эндонуклеазы рестрикции Bse II. Устаноблено, что носители генотипа GG пребосходили особей с генотипом AA и AG по показателям, Влияющим на формирование мясной продуктивности $(p<0,05)$. Из этого следует, что 6 исследуемой популяции частоты аллелей смещаются по закону Харди-Вайнберга. Генотип GG ябляется желательным при отборе на мясную продуктибность, так как есть значимые ассоциации с некоторыми признаками экстерьера. Таким образом, маркер rs 313744840 гена миостатина можно рекомендобать к использобанию 6 селекционных программах для отбора кур на побышение мясной продуктибности.
\end{abstract}

Ключебые слоба: куры, пушкинская порода, экстерьер, маркер, генотип, аллель.

Введение. Птица - один из важнейших источников мяса в рационе человека. Его биологическая ценность обусловлена высоким содержанием ненасыщенных жирных кислот в оптимальном для человека соотношении. Увеличение живой массы кур может повысить экономический потенциал птицеводческой отрасли [1]. Этого возможно достигнуть в результате должного воздействия на молекулярно-генетические механизмы регуляции процессов, лежащих в основе набора живой массы. Одним из таких механизмов может являться маркерная селекция с использованием локусов количественных признаков (QTL) - участков ДНК, связанных C конкретным фенотипическим признаком, изменение которого может быть измерено количественно [2]. Изучение QTL позволяет лучше понять генетическую архитектуру признаков и выявить области генома, которые контролируют количественные признаки [3]. Научный прогресс привел К значительному росту продуктивности, в том числе, благодаря использованию генетических маркеров, но молекулярные механизмы онтогенеза все еще остаются неясными и нуждаются в изучении.

В литературе представлены данные о взаимодействии между однонуклеотидными заменами (SNP), связанными со скоростью роста у цыплят в различные периоды их онтогенеза. Отмечается, что ассоциации SNP со скоростью роста могут быть различными в разные периоды роста птицы [4]. На данные процессы влияют такие показатели, как условия содержания и кормления, наследственность. В условиях интенсивного производства наиболее важным фактором, влияющим на рост и развитие птицы, является наследственность. Рост - это количественный признак, регулируемый несколькими генами, такими как миогенные регуляторные факторы (MRF), инсулиноподобный фактор роста 1 / рецептор инсулиноподобного фактора роста 1 (IGF -I / IGF-IR), миостатин (MSTN) и др. Следовательно, изучение молекулярных механизмов регуляции роста птицы яв- 


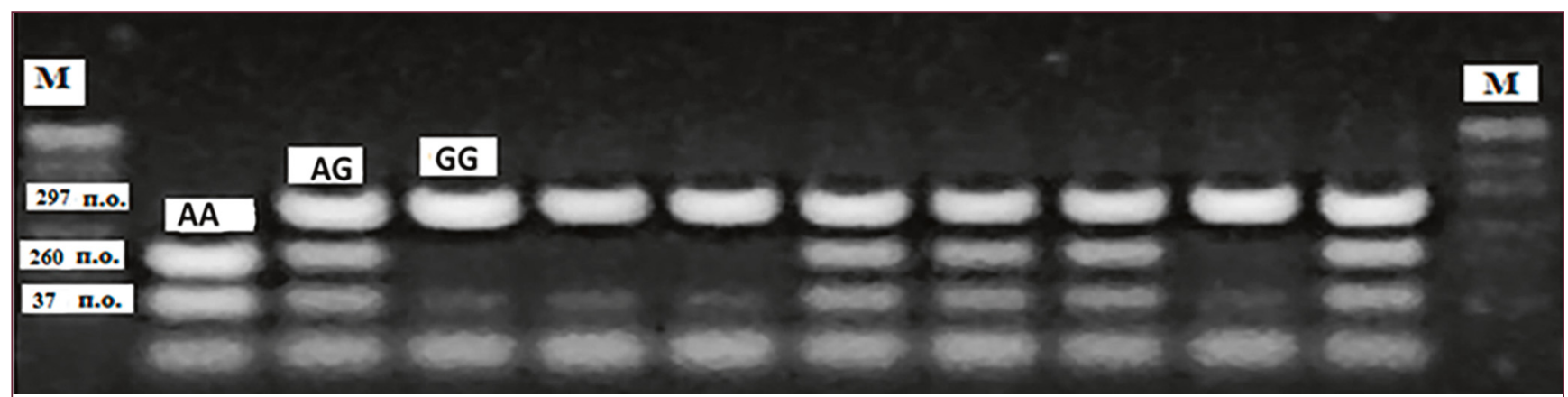

Рисунок 1. Детекция полиморфизма rs313744840 с помощью ПЦР-ПДРФ анализа

ляется актуальной и значимой задачей [5].

Для увеличения мясной продуктивности в птицеводстве применяется генетический анализ, который способствует отбору по желаемому признаку. Одним из основополагающих факторов, определяющих рост и развитие мышечной массы, является белок миостатин, известный как фактор роста дифференцировки-8 (GDF-8), кодируемый геном MSTN. Этот белок также является членом суперсемейства TGF- $\beta$, который экспрессируется в тканях скелетных мышц, где играет ключевую роль как негативный регулятор роста и развития мышц [6]. Миостатин подавляет развитие мышц за счет клеточной дифференцировки развивающихся сомитов на эмбриональной стадии и роста миофибриллярных клеток у взрослых особей [7,8]. В связи с этим ген MSTN и продукт его экспрессии заслуживают особого внимания.

Целью исследования было выявление связи SNP rs313744840 в гене MSTN с экстерьерными показателями у кур пушкинской породы.

Материал и методика исследований. Исследования проводили на базе лаборатории молекулярной генетики ВНИИГРЖ. В качестве объекта исследования была выборка из 102 голов кур породы пушкинская биоресурсной коллекции ВНИИГРЖ «Генетическая коллекция редких и ис- чезающих пород кур» (г. Пушкин, Санкт-Петербург). У птицы проводился индивидуальный учет продуктивных признаков. В возрасте 330 дней были проведены взвешивание и оценка особей по экстерьерным показателям. Были измерены следующие 16 экстерьерных параметров (см): с помощью циркуля - длина корпуса, длина корпус+шея, косая длина туловища (КДТц), длина бедра, глубина груди, ширина груди в ключицах, ширина таза; с помощью ленты - обхват груди, обхват плюсны, обхват голени, угол груди (градус), длина киля, длина плюсны, длина голени, косая длина туловища (КДТл).

Кровь для генотипирования отбирали у кур в возрасте 21 день из вены крыла в микропробирки Эппендорфа (500 мкл), содержащие в качестве антикоагулянта 50 мкл 0,5 М ЭДТА. До использования образцы хранили в холодильнике при $-20^{\circ} \mathrm{C}$. Экстракцию геномной ДНК проводили по стандартной методике с использованием протеиназы К и фенола [9]. Концентрацию и очистку выделенной ДНК осуществляли с помощью прибора Nano Drop2000 (Thermo Fisher Scientific, США). Для генотипирования использован метод полимеразной цепной реакции с определением полиморфизма длины рестрикционных фрагментов (ПЦР-ПДРФ) [10].

Реакцию проводили на амплификаторе «Bio-Rad» (США) с применением праймеров F 5'-AACCAATCGTCGGTTTTGAC-3', RV 5'-CGTTCTСTGTGGGCTGACTA-3' и режима, состоящего из 35 циклов: 30 сек $-94^{\circ} \mathrm{C}, 30$ сек $-60^{\circ} \mathrm{C}$, 30 сек $-72^{\circ} \mathrm{C}$. Для рестрикции в пробирку добавляли 0,2 мкл рестриктазы Bse 1 I (SibEnzyme, Новосибирск), перемешивали и ставили на инкубацию на 2 ч при $47^{\circ} \mathrm{C}$. Для электрофореза использовали 2,5\% агарозные гели, содержащие флуоресцентный краситель бромистый этидий и ТВЕ-буфер (45 мМ трис-борат, 1 мМ ЭДТА). Смесь после рестрикции вносили в лунки геля. Электрофорез проводили в течение 15 мин при рабочем напряжении $180 \mathrm{~V}$. В качестве маркера, позволяющего оценить длину фрагментов, использовали ДНК-маркер Step 100 (DIA-M). Сигнал флуоресценции фотографировали в системе гельдокументации фирмы Кodaк.

Полученный ампликон имел размер 297 п.о. Гетерозиготы AG отличались наличием трех фрагментов 297, 260 и 37 п.о., гомозиготы АА имели фрагменты 260 и 37 п.о., а у особей с генотипом GG был один фрагмент размером 297 п.о., который соответствует молекулярной массе амплифицированного участка (рис. 1).

На основании данных ПЦРПДРФ проводили многофакторный дисперсионный анализ для различия по экстерьерным показателям между генотипами кур в пакете программ SigmaPlot (вер- 
Таблица 1. Частоты генотипов и аллелей по однонуклеотидной замене rs313744840 в опытной популяции кур пушкинской породы

\begin{tabular}{|c|c|c|c|c|c|c|}
\hline Порода & $\mathbf{n}$ & & ота генот & & Часто & лелей \\
\hline \multirow{2}{*}{ уушкинская } & \multirow{2}{*}{102} & AA $n=13$ & AG $n=16$ & GG $n=73$ & A & G \\
\hline & & 0,13 & 0,16 & 0,71 & 0,21 & 0,79 \\
\hline
\end{tabular}

сия 12.0.) с использованием критериев Шапиро-Уилка и t-критерия Стьюдента [11]. Расчеты производили с помощью пакета GGally, визуализацию данных - при помощи пакета ggbiplot R v. 4.1.0.

Результаты исследований и их обсуждение. В результате ПЦР-ПДРФ-анализа в популяции кур выявлено три генотипа по изучемой SNP: AA, AG, GG. Распределение генотипов представлено в табл. 1.

Частота встречаемости мономорфного генотипа GG значительно превосходила остальные генотипы (АА и АG). Аллель А в исследуемой группе встречался относительно редко $(0,21)$, тогда как частота встречаемости аллеля $\mathrm{G}$ находилась на уровне 0,79.

чтобы оценить давление отбора на популяцию, мы рассчитали отклонение наблюдаемой гетерозиготности от ожидаемой. Для этого использовали кри- терий Пирсона $\left(\chi^{2}\right)$. Отмечено нарушение равновесия в популяции по Харди-Вайнбергу, что подтверждается значением $\chi^{2}=35,4$. Очевидно, это связано с непропорциональным отбором в данной популяции кур, т.к. в процессе ее селекции главными критериями были не только генотип особи, но и воспроизводительные качества родительских особей (яйценоскость, масса яйца).

Анализ главных компонент показывает положительную связь экстерьерных показателей с генотипами, так как все вектора сонаправленны с осями РС1-РС2. Векторы длины корпуса и угла груди находятся перпендикулярно друг другу, т.е. коэффициент корреляции равен 0, (так как косинус 90 градусов равен 0), и связи между данными показателями не наблюдается. Вектор угол груди длиннее по сравнению с остальными при- знаками, вклад по этому экстерьерному признаку больше в данной популяции. Положительная корреляционная связь наблюдается между КДТ, длинами корпуса и корпус+шея (чем меньше угол между векторами, тем сильнее связь между показателями экстерьера; рис. 2).

Основными признаками, влияющими на мясную продуктивность, являются обхват груди, глубина груди, длина киля грудной кости, размеры грудных и ножных мышц [12-14]. Достоверное влияние экстерьерных показателей на живую массу оценивали по коэффициенту корреляции ${ }^{\circledR}$. Существенное влияние $(p<0,05)$ на живую массу оказывали ширина груди $(r=0,65)$, обхват голени $(r=0,60)$, длина корпуса $(r=0,67)$, длина корпуса+шея $(r=0,69)$, КДТ $(r=0,69)$, угол груди $(r=0,55)$. Влияние rs313744840 на живую массу и показатели экстерьера представлено в табл. 2.

В результате многофакторного дисперсионного анализа обнаружили достоверные различия по ассоциациям генотип-признак. Куры с генотипом GG зна-

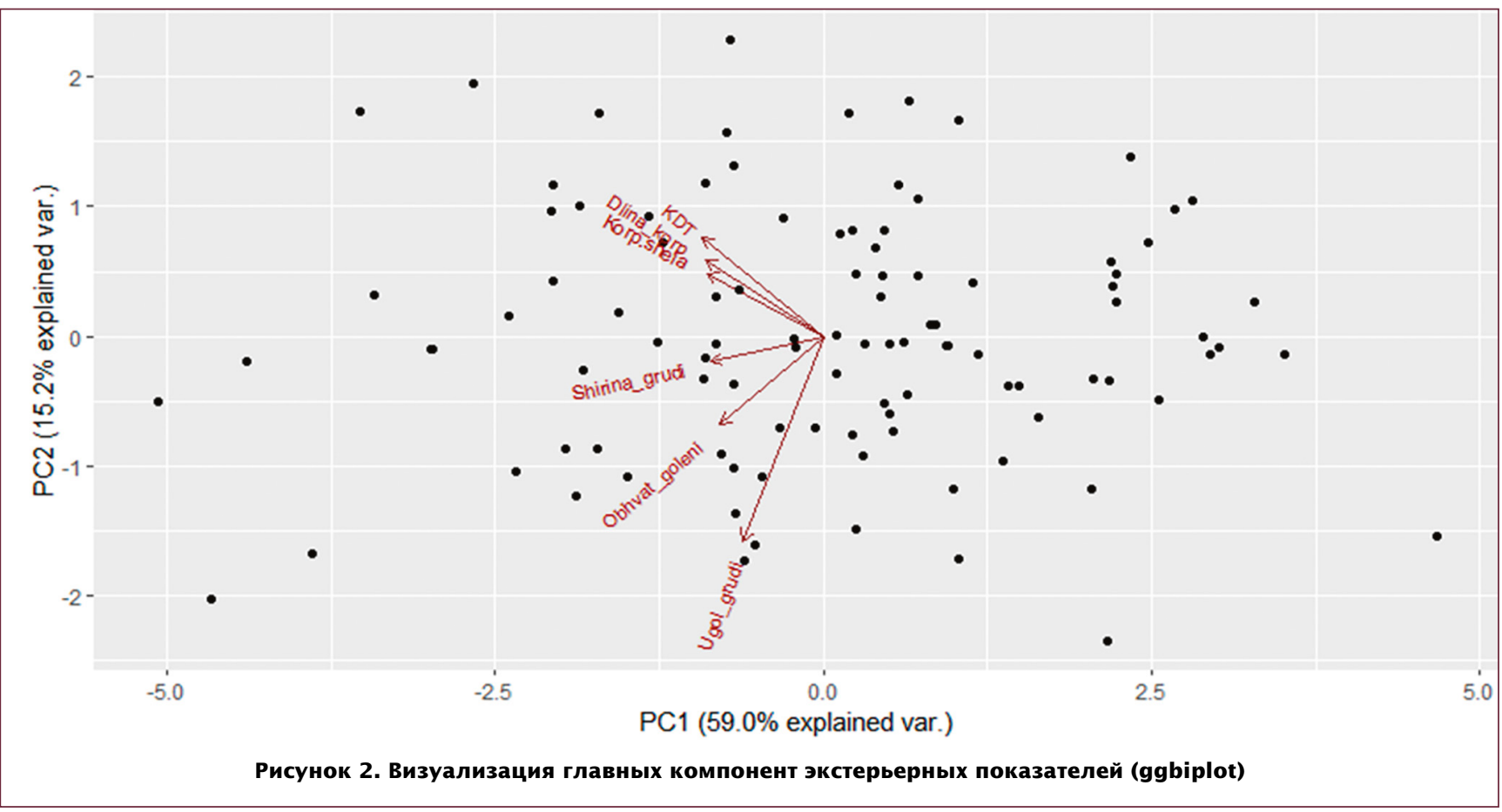




\begin{tabular}{|c|c|c|c|c|c|c|c|c|}
\hline \multirow{3}{*}{ № } & \multirow{3}{*}{ Показатель } & \multicolumn{6}{|c|}{ Генотип } & \multirow{3}{*}{$\begin{array}{c}\text { Уровень } \\
\text { достоверности }\end{array}$} \\
\hline & & \multicolumn{2}{|c|}{$\mathrm{AA}(n=13)$} & \multicolumn{2}{|c|}{ AG $(n=16)$} & \multicolumn{2}{|c|}{ GG $(n=73)$} & \\
\hline & & $M \pm m$ & Cv, \% & $\mathbf{M} \pm \mathbf{m}$ & Cv, \% & $\mathbf{M} \pm \mathbf{m}$ & Cv, \% & \\
\hline 1 & $\begin{array}{c}\text { Живая масса в } 330 \\
\text { дней, г }\end{array}$ & $2168 \pm 74,5^{1} \mathrm{a}$ & 12,4 & $2206 \pm 89,8^{2 b}$ & 15,2 & $2348 \pm 37,4^{23} c$ & 13,8 & $\begin{array}{l}1 \mathrm{a}-2 \mathrm{~b}-\mathrm{- \mu} \\
1 \mathrm{a}-3 \mathrm{c}-\mathrm{- \mu} \\
2 \mathrm{~b}-3 \mathrm{c}-\mathrm{-д}\end{array}$ \\
\hline 2 & Длина корпуса, см & $17,6 \pm 0,37^{1 a}$ & 7,7 & $18,2 \pm 0,30^{2 b}$ & 6,26 & $18,6 \pm 0,14^{3 c}$ & 6,4 & $\begin{array}{c}1 a-2 b-н д \\
1 a-3 c-p<0,05 \\
2 b-3 c-н д\end{array}$ \\
\hline 3 & Корпус+шея, см & $32,5 \pm 0,4^{1 a}$ & 4,4 & $32,9 \pm 0,42^{2 b}$ & 5,0 & $34,0 \pm 0,21^{3 c}$ & 5,4 & $\begin{array}{c}1 a-2 b-н д \\
1 a-3 c-p<0,05 \\
2 b-3 c-p<0,05\end{array}$ \\
\hline 4 & КДТц, см & $17,4 \pm 0,16^{1 a}$ & 3,3 & $17,8 \pm 0,21^{2 b}$ & 4,5 & $18,1 \pm 0,09^{3 c}$ & 4,3 & $\begin{array}{c}1 a-2 b-н д \\
1 a-3 c-p<0,05 \\
2 b-3 c-н д\end{array}$ \\
\hline 5 & Длина киля, см & $10,5 \pm 0,24^{1 a}$ & 7,6 & $11,1 \pm 0,32^{2 b}$ & 10,8 & $12,1 \pm 1,28^{3 c}$ & 89,2 & $\begin{array}{l}1 \mathrm{a}-2 \mathrm{~b}-\mathrm{-н} \\
1 \mathrm{a}-3 \mathrm{c}-\mathrm{нд} \\
2 \mathrm{~b}-3 \mathrm{c}-\mathrm{Hд} \\
\end{array}$ \\
\hline 6 & Длина плюсны, см & $9,82 \pm 0,14^{1 a}$ & 5,2 & $10,04 \pm 0,14^{2 b}$ & 5,5 & $9,97 \pm 0,06^{3 c}$ & 5,4 & $\begin{array}{l}1 \mathrm{a}-2 \mathrm{~b}-н д \\
1 \mathrm{a}-3 \mathrm{c}-\mathrm{- \mu} \\
2 \mathrm{~b}-3 \mathrm{c}-\mathrm{нд}\end{array}$ \\
\hline 7 & Длина голени, см & $13,0 \pm 0,21^{1 a}$ & 6,0 & $13,1 \pm 0,16^{2 b}$ & 5,2 & $12,9 \pm 0,10^{3 c}$ & 7,3 & $\begin{array}{l}1 a-2 b-н д \\
1 a-3 c-н д \\
2 b-3 c-н д\end{array}$ \\
\hline 8 & Длина бедра, см & $8,91 \pm 0,08^{1 a}$ & 3,2 & $9,30 \pm 0,13^{2 b}$ & 5,3 & $9,08 \pm 0,07^{3 c}$ & 7,0 & $\begin{array}{l}1 \mathrm{a}-2 \mathrm{~b}-\mathrm{- \mu} \\
1 \mathrm{a}-3 \mathrm{c}-\mathrm{- \mu} \\
2 \mathrm{~b}-3 \mathrm{c}-\mathrm{-д}\end{array}$ \\
\hline 9 & Глубина груди, см & $11,4 \pm 0,15^{1 a}$ & 4,8 & $11,6 \pm 0,14^{2 b}$ & 7,7 & $11,8 \pm 0,08^{3 c}$ & 5,7 & $\begin{array}{l}1 \mathrm{a}-2 \mathrm{~b}-\mathrm{нд} \\
1 \mathrm{a}-3 \mathrm{c}-\mathrm{Hд} \\
2 \mathrm{~b}-3 \mathrm{c}-\mathrm{Hд} \\
\end{array}$ \\
\hline 10 & $\begin{array}{l}\text { Ширина груди в } \\
\text { ключицах, см }\end{array}$ & $6,29 \pm 0,15^{1 a}$ & 8,9 & $6,52 \pm 0,15^{2 b}$ & 9,0 & $6,96 \pm 0,06^{3 c}$ & 7,9 & $\begin{array}{c}1 a-2 b-н д \\
1 a-3 c-p<0,05 \\
2 b-3 c-p<0,05\end{array}$ \\
\hline 11 & Ширина таза, см & $8,95 \pm 0,24^{1 a}$ & 9,7 & $9,02 \pm 0,16^{2 b}$ & 6,6 & $9,46 \pm 0,08^{3 c}$ & 8,4 & $\begin{array}{l}1 \mathrm{a}-2 \mathrm{~b}-\mathrm{нд} \\
1 \mathrm{a}-3 \mathrm{c}-\mathrm{- \mu} \\
2 \mathrm{~b}-3 \mathrm{c}-\mathrm{-д} \\
\end{array}$ \\
\hline 12 & КДТл, см & $21,7 \pm 0,26^{1 a}$ & 4,3 & $21,9 \pm 0,31^{2 b}$ & 5,7 & $21,5 \pm 0,11^{3 c}$ & 4,5 & $\begin{array}{l}1 \mathrm{a}-2 \mathrm{~b}-\mathrm{- \mu} \\
1 \mathrm{a}-3 \mathrm{c}-\mathrm{-д} \\
2 \mathrm{~b}-3 \mathrm{c}-\mathrm{-д}\end{array}$ \\
\hline 13 & Длина голень, см & $15,1 \pm 0,22^{1 a}$ & 5,2 & $15,2 \pm 0,22^{2 b}$ & 5,5 & $14,8 \pm 0,10^{3 c}$ & 5,9 & $\begin{array}{l}1 \mathrm{a}-2 \mathrm{~b}-\mathrm{нд} \\
1 \mathrm{a}-3 \mathrm{c}-\mathrm{нд} \\
2 \mathrm{~b}-3 \mathrm{c}-\mathrm{-д}\end{array}$ \\
\hline 14 & Обхват груди, см & $34,3 \pm 0,62^{1 a}$ & 6,5 & $34,9 \pm 0,39^{2 b}$ & 4,1 & $35,4 \pm 0,22^{3 c}$ & 5,4 & $\begin{array}{l}1 \mathrm{a}-2 \mathrm{~b}-\mathrm{- \mu} \\
1 \mathrm{a}-3 \mathrm{c}-\mathrm{нд} \\
2 \mathrm{~b}-3 \mathrm{c}-\mathrm{-д}\end{array}$ \\
\hline 15 & Обхват плюсны, см & $3,99 \pm 0,05^{1 \mathrm{a}}$ & 5,2 & $4,1 \pm 0,05^{2 b}$ & 4,8 & $4,10 \pm 0,02^{3 c}$ & 4,8 & $\begin{array}{l}1 \mathrm{a}-2 \mathrm{~b}-\mathrm{нд} \\
1 \mathrm{a}-3 \mathrm{c}-\mathrm{нд} \\
2 \mathrm{~b}-3 \mathrm{c}-\mathrm{нд} \\
\end{array}$ \\
\hline 16 & Обхват голени, см & $11,4 \pm 0,21^{1 \mathrm{a}}$ & 6,7 & $11,0 \pm 0,29^{2 b}$ & 10 & $12,2 \pm 0,11^{3 \mathrm{c}}$ & 8,2 & $\begin{array}{c}1 a-2 b-н д \\
1 a-3 c-p<0,05 \\
2 b-3 c-p<0,05\end{array}$ \\
\hline 17 & Угол груди, град. & $72,4 \pm 1,50^{1 a}$ & 7,5 & $68,6 \pm 1,26^{2 b}$ & 6,9 & $73,5 \pm 0,73^{3 c}$ & 8,6 & $\begin{array}{c}1 \mathrm{a}-2 \mathrm{~b}-\mathrm{p}<0,05 \\
1 \mathrm{a}-3 \mathrm{c}-\mathrm{Hд} \\
2 \mathrm{~b}-3 \mathrm{c}-\mathrm{Hд}\end{array}$ \\
\hline
\end{tabular}

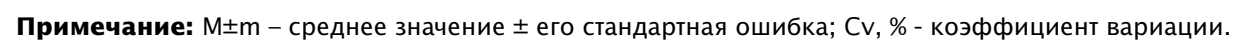

чительно и достоверно $(\mathrm{p}<0,05)$ превосходили особей с генотипами АA и АС по большинству показателей (см): длине корпуса $(18,6 \pm 0,14)$, длине корпуса+шея $(34,0 \pm 0,21)$, косой длине туловища $(18,1 \pm 0,09)$, ширине груди в ключицах $(6,96 \pm 0,06)$, обхвату голени GG $(12,2 \pm 0,11)$, и углу груди $(73,5 \pm 0,73)$. По остальным показателям достоверная связь не выявлена.
Коэффициент изменчивости обхвата голени и ширины груди в ключицах варьировал от 6,7 до $10 \%$; изменчивость признака корпус+шея варьировала от 4,4 до 5,4\%. Очевидно, такие невысокие показатели изменчивости обусловлены консолидированным отбором в данной популяции кур по этим признакам.

Заключение. Таким образом, SNP-маркер rs313744840 гена миостатина, ассоциированный с рядом экстерьерных признаков, можно рекомендовать $\mathrm{k}$ использованию в селекционных программах для отбора кур на улучшение мясной продуктивности и для последующего размножения популяции кур пушкинской породы.

Исследование Выполнено 6 рамках государственного задания 0445-2021-0010. 


\section{Литература}

1. Lee J. Muscle hyperplasia in Japanese quail

by single amino acid deletion in MSTN propeptide / J. Lee, D.H. Kim, K. Lee // Intl. J. Mol. Sci. - 2020. - V. 21 , No 4.- P. 1504.

2. Members of the Complex Trait Consortium. The nature and identification of quantitative trait loci: a community's view // Nat. Rev. Genet. - 2003. - V. 4. - P. 911-916.

3. Lien C.Y. Detection of QTL for traits related to adaptation to sub-optimal climatic conditions in chickens / C.Y Lien, M. Tixier-Boichard, S.W. Wu, W.F. Wang, C.S. Ng, C.F. Chen // Genet. Sel. Evol. - 2017. - V. 49, No 1. - P. 39.

4. Li F.G. A time-dependent genome-wide SNP-SNP interaction analysis of chicken body weight / F.G. Li, H. Li // BMC Genomics. 2019. - V. 20. - P. 771

5. Wu P. Transcriptome for the breast muscle of Jinghai yellow chicken at early growth stages / P. Wu, X. Zhang, G. Zhang, F. Chen, M. He, T. Zhang, J. Wang, K. Xie, G. Dai // Peer J. - 2020. - V. 15, No 8. - P. 8950

6. Xu K. Effective MSTN gene knockout by AdV-delivered CRISPR/Cas9 in postnatal chick leg muscle / K. Xu, C.X. Han, H. Zhou, et al. // Intl. J. Mol. Sci. - 2020. - V. 21 , No 7. - P.2584.
7. Bhattacharya T.K. Comparative analysis of silencing expression of myostatin (MSTN) and its two receptors (ACVR2A and ACVR2B) genes affecting growth traits in knock down chicken / T.K. Bhattacharya, R. Shukla, R.N. Chatterjee, S.K. Bhanja // Sci. Rep. - 2019. V. 9, No 1. - P. 7789.

8. Cao H. Chronological expression of PITX2 and SIX 1 genes and the association between their polymorphisms and chicken meat quality traits / H. Cao, W. Zhou, Y. Tan [et al.] // Animals. - 2021. - V. 11, No 2. - P. 445

9. Мазин А.В. Методы молекулярной генетики и генной инженерии / А.В. Мазин, К.Д. Кузнеделов, А.С. Краев. - М.: Ин-т цитологии и генетики, 1990. - С. 13-14.

10. Юрченко О.П. Гетерогенный подбор при разведении пушкинской породы кур / О.П. Юрченко, А.В. Макарова, А.Б. Вахрамеев // Генетика и разведение животных. 2017. - №3. C. 51-57.

11. Дементьева Н.В., Вахрамеев А.Б., Ларкина Т.А., Митрофанова О.В. Эффективность использования SNP-маркеров в гене MSTN в селекции кур пушкинской породы // Baвиловский журнал генетики и селекции. 2019. - T. 23. - №8. - С. 993-998.
12. Митрофанова О.В., Динамика экстерьерных показателей у кур при отборе по полиморфным вариантам в гене миостатина / О.В. Митрофанова, Н.В. Дементьева, Т.А. Ларкина // Изв. Нижневолжского агроунив. комплекса: наука и ВПО. - 2019. T. 54. - №2. - С. 222-228.

13. Dou T. Genetic architecture and candidate genes detected for chicken internal organ weight with a $600 \mathrm{~K}$ single nucleotide polymorphism array / T. Dou, M. Shen, M. Ma, L. Qu, Y. Li, Y. Hu, J. Lu, J. Guo, X. Wang, K. Wang // Asian-Australas. J. Anim. Sci. 2019. - V. 32, No 3. - P. 341-349.

14. Пегливанян Г.К. Ассоциация показателей экстерьера опытной популяции кур пушкинской породы с эффективным маркером rs316247861 гена миостатина / Г.К. Пегливанян, Т.А. Ларкина, О.Ю. Баркова, Н.В. Дементьева // Генетика и разведение животных. - 2020. - №3. - С. 33-38.

\section{Для контакта с автором:}

Пегливанян Григорий

Карапетович

E-mail:

peglivanian_grig@mail.ru

\title{
Relationships of Exterior Parameters in Pushkin Chickens with Single Nucleotide Polymorphism rs313744840 in the Myostatin Gene
}

\author{
Peglivanyan G.K.

\section{Russian Research Institute of Farm Animal Genetics and Breeding - branch of the L.K. Ernst Federal Research} \\ Center for Animal Husbandry
}

\begin{abstract}
Summary: Improving of the genotype with the use of DNA markers ensures accurate selection and accelerates the selection process in animal husbandry. Body weight and quality of meat depend on a variety of genes and are closely related to the development of skeletal muscles. The effects of single nucleotide polymorphism (SNP) rs313744840 in the myostatin gene on the parameters of the exterior in chickens were studied on 102 birds of Pushkin breed. The assessment of the exterior was carried out at 330 days of age using 17 parameters: body weight, body length, body and neck length, body length, hip length, chest depth, chest width in the clavicles, pelvic width, chest circumference, metatarsal circumference, lower leg circumference, metatarsal length, lower leg length, oblique body length, lower leg length, chest angle (degree), keel length. The PCR-RFLP (restriction fragment length polymorphism) genotyping of the SNP was performed using the restriction endonuclease Bse ll. Two alleles $(A$ and $G)$ and three genotypes were found; carriers of the dominating $G G$ genotype were significantly ( $p<0.05)$ superior to $A A$ and $A G$ individuals in terms of almost all exterior parameters affecting meat productivity. In the studied population allele frequencies shifted according to the Hardy-Weinberg law. The GG genotype is preferable for the selection of this breed for meat productivity due to the significant associations with practically important exterior parameters. The conclusion was made that SNP marker rs313744840 in the myostatin gene can be recommended for use in breeding programs for chickens involving the selection for improved meat productivity and for further selection of Pushkin breed.
\end{abstract}

Keywords: chicken, Pushkin breed, exterior parameters, marker, genotype, allele. 